\title{
TEKNIK PEMBUATAN PROPOSAL PENELITIAN
}

\author{
Firman Firman \\ Jurusan Bimbingan dan Konseling FIP UNP \\ Email : firman@konselor.org
}

\section{Pendahuluan}

Peneliti dituntut memiliki kepekaan dan kemauan untuk mendapat jawaban secara ilmiah terhadap berbagai masalah dalam kehidupan masyarakat. Sebelum melaksanakan penelitian, peneliti dibekali dengan berbagai pengetahuan dan keterampilan serta teoriteori sesuai dengan bidang kajian yang ditekuninya. Istilah metodologi (methodology) dengan metoda (methods) tidak jarang tumpang tindih penggunaannya. Sebenarnya metodogi (methodology) merupakan studi yang logis dan sistematis tentang prinsip-prinsip yang mengarahkan penelitian ilmiah, yang intinya terdiri dari : masalah, tinjauan pustaka, kerangka teori (jika ada), hipotesis (jika ada) dan cara penelitian. Sedangkan metoda (methods) merupakan cara untuk melakukan penelitian, menyangkut dengan bahan, alat, jalan penelitian, variabel penelitian dan analisis hasil.

Metoda penelitian pada prinsipnya menceritakan cara yang merupakan alat (tod) mencapai tujuan. Cara yang dilakukan dalam penelitian bervariasi dan tidak kaku serta tergantung dari objek formal ilmu pengetahuan tersebut, tujuan serta jenis data yang akan 
diungkapkan. Penelitian umumnya mengandung dua ciri, yaitu logika dan pengamatan emperis (Babbie, $1986: 16$ ).

Penelitian ditujukan memecahkan masalah yang dihadapi untuk pengembangan ilmu pengetahuan dan permasahan umat manusia. Jawaban masalah tersebut menggunakan pendekatan ilmiah (scientific approach) yang pada gilirannya melahirkan metode ilmiah (scientific method). Upaya yang dilakukan dengan menggunakan metoda ilmiah disebut dengan penelitian ilmiah (scientific research).

Penelitian ilmiah adalah suatu bentuk upaya penyelidikan (investigation) terhadap suatu pernyataan (proposisi) hipotesis yang dijadikan sebagai jawaban sementara suatu masalah. Membedakan dengan bentuk penyelidikan lain, ada beberapa ketentuan pokok yang harus dipenuhi oleh pelakunya, Pertama, penelitian itu harus dilakukan secara sistematis, terkontrol, dan kritis. Kedua, penelitian ilmiah menghasilkan kebenaran ilmiah, bersifat menerangkan (explanatory), memprediksi (predictive) dan mengontrol (controlling).

Penelitian ilmiah adalah kegiatan yang bersifat indrawi (empirical) maksudnya, jawaban masalah yang diperoleh melalui kegiatan ini merupakan keyakinan subyektif peneliti namun telah teruji dengan kenyataan-kenyataan objektif di luar dirinya. Dengan kata lain, setiap pernyataan peneliti haruslah selalu didasarkan pada kebenaran 
yang diperoleh melalui pengujian dan penjelajahan yang bersifat empiris (empirical inquiry and test).

Keyakinan terhadap jawaban suatu masalah memerlukan upaya pengujian di luar dirinya sendiri. Dengan kata lain sesuatu yang dianggap benar secara subyektif dan teoritis perlu diverifikasi seberapa jauh kebenaran yang diduga itu ditemui pada kenyataan objektif (objective reality) di lapangan. Bila proposisi hipotesis-teoritis itu didukung oleh data yang ditemukan di lapangan barulah proposisi itu diterima sebagai jawaban masalah secara relatif meyakinkan. Namun bagaimanapun juga temuan tersebut masih tetap terbuka untuk diujikan lagi pada kesempatan lain. Barulah kemudian setelah menempuh ujian berkali-kali, proposisi tersebut dapat dijadikan sebagai teori keilmuan yang baru. Karena itu tidak mustahil temuan suatu penelitian akan ditolak oleh data pada kesempatan lain. Bila terjadi demikian maka kemungkinan tertolaknya temuan yang semula diharapkan akan menjadi unsur baru khasanah pengetahuan tidak dapat dihindarkan.

Kegiatan penelitian yang dilalui peneliti secara umum adalah ; (1) persiapan, (2) pelaksanaan, (3) pengolahan data,(4) pembuatan laporan dan (4) sosialisasi hasil penelitian. Uraian berikut akan difokuskan kepada persiapan penelitian. Selama proses mempersiapkan penelitian, kegiatan yang dilalui peneliti adalah : (1) 
mencari masalah penelitian, (2) mengumpulkan kegiatan penunjang untuk menjawab masalah tersebut, serta (3) penyusunan proposal penelitian.

\section{Masalah Penelitian}

Persoalan pertama dalam penelitian adalah menenemukan permasalahan apa yang akan diteliti. Kerlinger (1973:16) menjelaskan masalah adalah pertanyaan-pertanyaan yang dicoba untuk dicari jawabannya. Sedangkan Soerjono Soekamto (1982:109) menjelaskan suatu masalah sebenarnya merupakan proses yang mengalami halangan di dalam mencapai tujuannya. Biasanya halangan tersebut hendaknya diakhiri dan hal inilah salah satu hal yang menjadi tujuan penelitian.

Permasalahan penelitian muncul dari pertimbangan teoritis, pragmatis, atau kedua-duanya. Tidak ada pedoman yang baku yang bisa digunakan untuk membantu peneliti memilih isu penelitiannya. Sumber permasalahan bisa berasal dari pengalaman pribadi peneliti, informasi yang dibacanya, percakapan- percakapan, apa-apa yang diekspos di media masa, teori yang dipelajari, kejadian-kejadian yang dilihat sehari-hari, nilai yang dianut, dan lain sebagainya. Penelitian dilakukan guna mencapai tujuan tertentu. Suatu penelitian bisa mempunyai kegunaan praktis jika isu penelitian yang dipilih berkenaan 
dengan permasalahan yang hangat dan aktual di lingkungan masyarakat.

Permasalahan yang dimaksud dalam hal ini adalah pertentangan antara kondisi seharusnya dengan realita yang terjadi. Jika sekelompok pegawai selalu datang di atas jam kerja yang seharusnya maka terlihat adanya masalah. Jika produksi selalu tidak mencapai target, maka terdapat masalah. Seorang manajer pemasaran melakukan penelitian tentang kepuasan konsumen karena mulai banyak keluhan-keluhan dari mereka. Isu penelitian manajer tersebut adalah "kepuasan konsumen". Manajer produksi juga melakukan penelitian tentang pengendalian kualitas karena banyak barang yang ditolak oleh para pemesan. Isunya adalah "quality-control". Seorang mahasiswa mengambil isu "disiplin kerja" untuk penelitiannya, karena ketika datang ke suatu departemen ternyata pegawainya seringkali terlambat datang di kantor. Isu-isu penelitian tersebut tadi benarbenar didasarkan atas masalah yang nyata terjadi dan sasarannya adalah memecahkan masalah tersebut.

Penelitian dapat juga diawali dengan adanya imajinasi dan keinginantahuan yang kuat dari peneliti. Tanpa ada kejadian yang sangat istimewa (negatif/positif), seseorang bisa melakukan penelitian karena ada sesuatu hal yang ingin diketahuinya sendiri, guna kepentingan ilmunya sendiri. Seorang yang tertarik dalam bidang ilmu 
manajemen dapat saja meneliti efektivitas suatu program gugus kendali mutu bukan untuk kegunaan praktis, tetapi semata-mata ingin membuktikan teori yang dipelajarinya. Seseorang dapat juga meneliti budaya organisasi dengan tujuan "hanya" ingin mengetahuinya saja. Atau bahkan melakukan serangkaian penelitian dengan maksud menyusun suatu teori baru.

Pemilihan permasalahan perlu mempertimbangkan : kemampuan peneliti sehubungan dengan penguasaan teori dan metodologi, (2) sarana dan prasarana pendukung, (3) kemungkinan memperoleh data (4) kegunaan untuk kemaslahatan umum serta perkembangan ilmu pengetahuan

Kenyataan yang ditemui sering terjadi kesalahan dalam perumusan permasalahan yang dilakukan oleh peneliti. Kesalahan tersebut disebabkan antara lain oleh: (1) pengumpulan data dilakukan tanpa perencanaan yang matang, (2) tujuan yang dirumuskan secara umum dan meragukan sehingga hasil serta interpretasi tidak tepat, (3) batasan pendekatan tidak dipaparkan secara jelas.

Penelitian yang berangkat dari masalah faktual ( yang benar ada di suatu organisasi atau lingkungan tertentu), maka masalah tersebut harus diidentifikasikan. Identifikasi artinya merinci masalah sehingga dapat diketahui dengan jelas. Kalau misalnya masalahnya 
menyangkut dengan disiplin kerja di instansi atau organisasi $\mathrm{X}$, maka peneliti harus menjelaskan secara rinci tentang masalah disiplin kerja tersebut. Uraiannya berisi tentang pelanggaran-pelanggaran yang banyak dilakukan pegawai, atau perilaku-perilaku yang tidak sesuai dengan aturan yang telah ditetapkan. Misalnya, ada aturan yang mengharuskan pegawai masuk kerja pukul 07.00, tetapi dalam kenyataannya tidak demikian. Indentifikasi masalah sebaiknya disertai dengan data yang mendukungnya. Berapa banyak pegawai yang selalu datang terlambat? Berapa lama waktu keterlambatan tersebut? Di bagian mana yang paling banyak terjadi keterlambatan? Pegawai dari golongan mana yang paling banyak terlambat?.

Setelah diidentifikasikan, masalah penelitian harus dirumuskan. Perumusan masalah biasanya disusun dalam bentuk pertanyaan yang nantinya akan membentuk pertanyaan penelitian (reseach questions). Misalnya : Sejauhmana peraturan-peraturan yang ada dimengerti oleh pegawai? Bagaimana sanksi terhadap pelanggaran yang terjadi? Bagaimana akibat yang ditimbulkan dari adanya pelanggaran?., apakah terdapat korelasi antara tingkat pemahaman terhadap peraturan dengan tingkat pelanggaran? dan lain sebagainya. Karena perumusan masalah merupakan pertanyaan penelitian, maka hal tersebut merupakan patokan pertama pencarian data. 


\section{Penyusunan Proposal Penelitian}

\section{A. Perumusan Judul Penelitian}

Setelah permasalahan penelitian telah diperoleh dan kemudian dirumuskan, Kegiatan berikut adalah merumuskan judul penelitian.Judul penelitian berbeda dengan judul buku, ceritera pendek, puisi, atau artikel-artikel populer lainnya. Judul harus mampu menggambarkan secara cepat dan jelas tentang apa yang diteliti. Syarat judul penelitian adalah :

\section{Menggambarkan Variabel Penelitian}

Variabel penelitian adalah isu utama penelitian. Kalau isu utamanya adalah "motivasi kerja", maka kata "motivasi kerja" tersebut secara eksplisit harus ada dalam judulnya. Jika peneliti tidak sekedar ingin tahu tentang motivasi kerja saja, tetapi juga secara khusus ingin mengetahui bagaimana hubungannya dengan variabel lain, misalnya "kinerja", maka kata "kinerja" tersebut juga harus ada dalam judul penelitian. Walau judul penelitian harus menyebutkan variabelnya, tetapi yang disebutkan hanyalah variabel utama yang dijadikan isu penelitian. Misalnya variabel utamanya adalah "motivasi kerja", tetapi penelitian tersebut tidak sekedar mengetahui motivasi kerja saja. Peneliti juga menganalisis motivasi kerja dari perspektif jenis kelamin, usia, pendidikan, dan 
lain sebagainya. Kesemua perspektif tersebut merupakan variabelvariabel penelitian yang tidak harus disebutkan dalam judul.

\section{Unit Analisis Harus Dipaparkan Secara Jelas}

Unit analisis dimaksud dalam uraian ini adalah organisasi, kelompok orang, kejadian, atau hal-hal lain yang dijadikan objek penelitian. Masih dengan isu "motivasi kerja", maka judul penelitian juga harus secara eksplisit mencantumkan "siapa" yang ditelitinya secara lebih definitif. Kalau yang diteliti adalah pegawai, maka kata "pegawai" harus disebutkan di dalam judul penelitian. Kalau yang diteliti adalah konsumen, kata "konsumen" harus disebutkan. Pegawai, konsumen dalam contoh di atas adalah unit analisis. Jika seseorang ingin meneliti sistem penggajian suatu instansi, maka unit analisisnya adalah instansi atau organisasi.

\section{Memaparkan Lokasi Penelitian}

Lokasi penelitian adalah tempat di mana unit analisis penelitian berada. Jika pegawai merupakan unit analisis, maka harus disebutkan secara definitif di organisasi mana pegawai tersebut bekerja. Apabila pelitian dilakukan di wilayah tertentu, secara jelas nama wilayah tersebut harus dicantumkan dalam judul 
penelitian. Jika unit analisisnya organisasi, maka disebutkan pula letak di mana organisasi tersebut berada.

\section{Diungkapkan Dengan Singkat dan Jelas}

Walau judul harus disusun sesingkat mungkin tetapi tidak berarti lalu menjadi tidak jelas. Arti sesingkat mungkin adalah hindari kata-kata yang tidak seharusnya ada dalam judul, karena tanpa kata-kata tersebut juga, makna judul sudah dapat dimengerti.

\section{B. Latar Belakang}

Bagian latar belakang menggambarkan secara utuh dan menyatu tentang: tema sentral masalah yang dikaji, mekanisme proses timbulnya masalah tersebut, motivasi yang mendasari dilakukan penelitian dan harapan yang diinginkan dari pelaksanaan penelitian.

Tema sentral masalah yang menjadi kajian dalam penelitian bersifat kondisional atau situasional yang didalamnya terdapat tantangan, tuntutan dan kesempatan. Sehubungan dengan hal itu tidak jarang dalam pengukapan tema sentral masalah penelitian diungkapkan terlebih dahulu fenomena atau gejala yang dihadapi 
serta akibatnya. Kehangatan, aktualitas serta relevansi perlu menjadi bahan pertimbangan.

Mekanisme timbulnya masalah yang diungkapkan dalam latar belakang masalah juga memaparkan proses terjadinya masalah dari awal sampai dewasa ini yang belum tersentuh secara lengkap dan utuh dalam suatu bidang ilmu sehingga menjadi masalah dalam kehidupan masnusia.

Agar peneliti dapat menyusun latar belakang penelitiannya dengan baik maka dia harus membekali diri dengan banyak informasi tentang isu penelitiannya baik yang berdimensi praktis dan teoritis. Seorang peneliti dengan isu "motivasi kerja", harus dapat menjelaskan mengapa dia meneliti isu tersebut, apa akibat positif yang bisa ditimbulkan dari penelitian dengan isu tersebut. Dalam latar belakang peneliti bisa saja mencantumkan data atau pendapat-pendapat orang lain guna memperkuat alasan penelitiannya.

\section{Rumusan Masalah}

Pokok permasalahan ditentukan dengan memilih pokok permasalahan yang diungkapkan pada awalnya sangat umum dan berlanjut kepada uraian yang lebih bersifat spesifik Fokus penelitian menggambarkan rincian pernyataan atau topik-topik 
pokok yang akan diungkapkan melalui penelitian. Apabila digunakan rumusan masalah, fokus penelitian berisi pernyataanpernyaaan yang akan dijawab dalam penelitian dan alasan diajukannnya pernyataan. Pernyataan-pernyataan ini diajukan untuk mengetahui gambaran apa yang akan diungkapkan di lapangan.

\section{D.Tujuan Penelitian}

Tujuan penelitian merupakan sasaran hasil yang ingin di capai dalam penelitian ini sesuai dengan fokus yang telah dirumuskan.Tujuan penelitian dirumuskan secara utuh dan berorientasi kepada pertanyaan-pertanyaan dalam permasalahan (fokus penelitian). Dari tujuan penelitian tercermin langkah operasional penelitian yang akan dilakukan.

Pencantuman tujuan penelitian dimaksudkan agar peneliti senantiasa bergerak sesuai dengan tujuan tersebut. Apabila tujuan penelitian adalah ingin mengetahui hubungan antara satu variabel dengan variabel lainnya, maka peneliti harus selalu berupaya ke arah situ. Apabila peneliti bertujuan ingin mengetahui sikap pegawai tentang sesuatu hal maka dia harus. mengarahkan semua upaya penelitiannya, yaitu memperoleh data tentang sikap 
pegawai. Tercapai tidaknya tujuan penelitian secara eksplisit harus tampak dalam hasil penelitian dan dalam kesimpulan penelitian.

\section{E. Kegunaan Penelitian}

Kegunaan penelitian ditunjukan untuk pengembangan ilmu dan guna laksana dalam pembangunan. Melalui paparan ini dapat disimpulkan bahwa permasalahan yang diteliti layak dilaksanakan dan fungsional secara ilmiah dan paktis. Misalnya kalau ternyata terbukti bahwa ada hubungan antara gaji pegawai dengan semangat kerja mereka, lalu apa manfaat dari temuan tersebut bagi lingkungan di mana penelitian dilangsungkan?

\section{F. Kerangka Pemikiran}

Dalam kerangka pemikiran, peneliti harus menguraikan konsep atau variabel-variabel penelitiannya secara lebih rinci. Dia tidak hanya mendefinisikan variabel-variabel tadi, tetapi juga menjelaskan keterkaitan di antara variabel-variabel tadi. Menguraikan kerangka pikirannya , peneliti tidak sekedar memfokuskan pada variabel-variabel penelitiannya saja tetapi juga harus menghubungkan konsep penelitian dalam kerangka yang lebih luas lagi. Misalnya jika peneliti ingin mengetahui apakah ada korelasi antara gugus kendali mutu dengan tingkat produktivitas, maka 
peneliti menguraikan apa itu gugus kendali mutu, apa itu produktivitas, bagaimana hubungan di antara kedua variabel itu, lalu bagaimana keterkaitannya dengan organisasi secara menyeluruh.

Akhir kerangka pemikiran dapat disusun dalam bentuk model, yaitu abtraksi dari pemikiran-pemikiran yang melandasi penelitian. Model kerangka pemikiran bisa sama dengan model penelitian, tetapi juga bisa berbeda. Model penelitian cenderung lebih memusatkan pada variabel- variabel penelitian yang memang benar-benar akan diteliti, sedangkan model kerangka pemikiran lebih luas lagi. Misalnya, Model : $K=f(m, k)$ - Kinerja adalah fungsi dari motivasi dan kemampuan, tetapi penelitian hanya ingin mengetahui hubungan antara motivasi dengan kinerja. Dengan demikian dalam model kerangka pemikiran ada tiga variabel, sedangkan di model penelitian hanya ada dua variabel

\section{G. Menetapkan Hipotesis Penelitian}

Penelitian bisa menggunakan hipotesis atau bisa juga tidak, atau bahkan bisa pula memunculkan hipotesis. Yang dimaksud dengan hipotesis adalah tesis (kesimpulan) yang masih belum tentu benar (hypo). Karena belum tentu benar, maka perlu diuji. Pemunculan hipotesis didasarkan atas kerangka pemikiran. Peneliti dapat membuat hipotesis : "Makin tinggi tingkat pemahaman 
pegawai pada peraturan organisasi, makin sedikit tingkat pelanggaran yang dilakukannya". Hipotesis ini muncul berdasarkan kerangka pemikiran bahwa orang melanggar suatu peraturan karena dia tidak atau kurang mengerti tujuan atau kegunaan peraturan tersebut. Kerangka pemikiran ini didukung oleh teori-teori, atau penelitian-peneliti-an tertentu.

Peneliti tidak bisa sembarangan membuat hipotesis. Dia harus benar-benar cermat membuat hipotesis agar hipotesisnya bisa diterima. Suatu hipotesis bisa saja ditolak, tetapi jika penolakannya disebabkan karena kerangka berpikir yang salah, bukan karena salah pengambilan data atau hal teknis lainnya, maka mutu logika peneliti dipertanyakan.Suatu penelitian boleh mempunyai lebih dari satu hipotesis. Terlepas dari jumlah yang ada, semuanya harus diuji.

\section{H. KAJIAN PUSTAKA}

Kajian kepustakaan berfungsi sebagai dukungan, evidensi ilmiah yang relevan dengan masalah yang ditelit.Kajian teori bermanfaat sebagai pemandu agar fokus penelitian sesuai dengan kenyataan lapangan. Di samping itu landasan teori bermanfaat untuk memberikan gambaran umum tentang latar penelitian dan sebagai bahan pembahasan hasil penelitian. Peran landasan teori dalam penelitian kualitatif jauh berbeda dengan penelitian kuantitatif. 
Penelitian kuantitatif berangkat dari teori ke data serta berakhir pada penolakan atau penerimaan teori yang diajukan. Sedangkan penelitian kualitatif peneliti bertolak dari data, memanfaatklan teori sebagai bahan penjelas dan berakhir dengan suatu teori.

\section{METODE PENELITIAN}

\section{Penentuan Metode Penelitian}

Setelah peneliti sangat memahami apa yang akan ditelitinya, maka hal yang paling penting dalam proses penelitian adalah menentukan bagaimana cara menelitinya. Di sini peneliti harus bisa menetapkan metoda penelitian apa yang tepat. Kesalahan memilih metoda penelitian akan mengakibatkan tujuan yang sesungguhnya dari penelitian tidak akan tercapai.

Dalam ilmu-ilmu sosial banyak metode penelitian yang dipakai, antara lain survai, eksperimen, studi historis, studi kasus, dan lain-lain. Yin (1989) mengatakan bahwa ada tiga kondisi yang perlu dipertimbangkan dalam menetapkan metode penelitian apa yang akan dipakai.(1) jenis pertanyaan penelitian, (2) sejauhmana peneliti dapat mengendalikan kejadian atau perilaku obyek yang diteliti, dan (3) waktu kejadian atau perlilaku ditampilkan.

Apabila penelitian bertujuan ingin mengetahui bagaimana dan mengapa sesuatu hal itu terjadi peneliti mampu 
mengendalikan perilaku atau kejadian tersebut, perilaku serta kejadian yang akan diteliti adalah yang sekarang (kontemporer) maka metode penelitiannya adalah eksperimen. Misalnya peneleliti ingin mengetahui bagaimana pengaruh program pelatihan terhadap peningkatan kinerja. Peneliti dapat menggunakan rancangan penelitian eksperimen pretest posttest design.

Apa yang dikemukakan oleh Yin tersebut jangan dianggap sebagai suatu peraturan yang mengikat. Yin hanya bermaksud memberikan kemudahan manakala peneliti mengalami kesulitan dalam menentukan metoda penelitian apa yang harus diambilnya.

\section{Menentukan sampel penelitan}

Sebelum ditentukan sampel, peneliti harus menetapkan populasi penelitian karena sampel adalah bagian dari populasi.Misalnya penelitian dilakukan terhadap pegawai di Departemen X, maka semua pegawai di departemen itu adalah populasi. Penelitian terhadap desa di Kecamatan X, maka seluruh desa yang ada di kecamatan tersebut adalah populasi.

Penelitian yang ideal tidak menggunakan sampel. Tetapi karena keterbatasan waktu, dana, tenaga, yang dimiliki peneliti maka peneliti terpaksa harus mengambil sampel. Ada dua cara pengambilan sampel, yaitu dengan teknik probabilitas - sampel 
acak sederhana, sampel acak distaratifikasi, sampel sistematis, sampel gugus, dan lain sebagainya-dan teknik sampel nonprobabilitas- sampel bertujuan, sampel kebetulan, sampel "bolasalju", dan lain sebagai-nya. Penentuan teknik sampling dan jumlah sampel harus benar-benar seksama sehingga hasil penelitian dicapai sesuai dengan tujuan.

Tidak semua penelitian mempunyai populasi. Kalau penelitiannya adalah tentang sistem kerja di satu departemen, maka penelitiannya tidak mempunyai populasi. Departemen yang ditelitinya bukan disebut sampel tetapi dinamakan unit analisis. Jika dalam penelitian mengambil beberapa orang untuk diwawancarai untuk memperoleh keterangan tentang sistem kerja di departemen tersebut, maka mereka bukan dinamakan sampel, tetapi responden. Tetapi jika peneliti yang sama ternyata ingin mengetahui pendapat pegawai di depatemen tadi, maka peneliti perlu menentukan sampel. Dalam kasus terakhir ini unit analisisnya adalah individu.

\section{Menentukan Teknik Pengambilan Data}

Data adalah informasi yang berkaitan dengan variabel penelitian. Kalau variabelnya adalah motivasi kerja pegawai, maka datanya adalah informasi tentang motivasi kerja pegawai, bukan 
yang lain. Kalau variabelnya adalah upah atau gaji, maka informasinya berupa jumlah upah dan gaji yang berupa uang yang diterima. Yang menjadi pertanyaan penting adalah teknik pengambilan data yang bagaimana agar peneliti bisa memperoleh data yang diinginkannya. Bisakah data tentang upah dicari dengan teknik wawancara? Bisakah data disiplin kerja seseorang diambil melalui kuesioner yang diisi oleh orang yang bersangkutan?

Ada data primer dan sekunder. Data primer adalah data yang diambil oleh peneliti sendiri (bukan oleh orang lain) dari sumber utama, guna kepentingan penelitiannya, yang sebelumnya tidak ada. Data sekunder adalah data yang sudah tersedia yang dikutip oleh peneliti guna kepentingan penelitiannya. Data aslinya tidak diambil peneliti tetapi oleh pihak lain. Misalnya data tentang upah pegawai, jika jumlah upahnya diperoleh berdasarkan wawancara dengan pegawai yang bersangkutan, maka data upah tersebut adalah data primer. Jika data tentang upah tersebut dikutip oleh peneliti dari Daftar Upah Pegawai yang telah tersedia, maka data upah ini adalah data sekunder.

Beberapa teknik pengambilan data yang umum digunakan dalam penelitian sosial antara lain adalah wawancara, kuesioner, dan studi dokumentasi, dan observasi. Untuk masing-masing teknik pengambilan digunakan instrumen pengambilan data yang 
berbeda. Wawancara menggunakan panduan wawancara dan bisa dilengkapi dengan alat perekam suara (tape-recorder), kuesioner menggunakan daftar pertanyaan tertulis, studi dokumen dengan alat catat mencatat atau tustel, observasi dengan tustel, catatan, atau alat lainnya.

\section{Mengoperasionalisasikan Variabel Penelitian}

Variabel adalah sesuatu hal yang menjadi obyek penelitian yang mempunyai nilai yang bervariasi. Kalau peneliti tertarik meneliti disiplin kerja pegawai, maka disiplin kerja tersebut adalah variabel penelitiannya. Disiplin kerja mempunyai variasi nilai; disiplinnya tinggi, rendah, cukup, dan lain sebagainya. Besar atau banyaknya variabel penelitian tidak dapat dijadikan patokan tingkat keilmiahan suatu penelitian. Peneliti boleh saja memfokuskan penelitiannya pada satu variabel dan boleh juga dua, tiga, empat, dan entah berapa banyak lagi. Kadar keilmiahan suatu penelitian lebih banyak ditentukan oleh bagaimana peneliti menetapkan memilih dan menerapkan metode penelitiannya; misalnya menentukan sampel, mencari data, mengolah data, mengiterpretasikan data, dan lain sebagainya.

Operasionalisasi variabel merupakan proses mengubah definisi nominal menjadi definisi operasional. Misalnya definisi 
nominal dari disiplin adalah "tingkat kepatuhan seseorang kepada aturan-aturan yang dikeluarkan oleh organisasi". Definisi operasionalnya : Masuk pukul 07.00 dan pulang pukul 14.00, setiap tanggal 17 mengikuti apel, tidak merokok di tempat yang ada larangan merokok, meminta ijin kepada yang berwenang jika meninggalkan kantor pada saat jam kerja, dan lain sebagainya.

Definisi operasional tidak boleh mempunyai makna yang berbeda dengan definisi nominal. Oleh karena itu sebelum menyusun defenisi operasional, peneliti harus membuat definisi nominal terlebih dahulu variabel penelitiannya. Definisi nominal dari variabel penelitian seharusnya secara eksplisit telah dinyatakan dalam kerangka pemikiran. Definisi nominal dapat diangkat dari berbagai pendapat para akhli yang memang banyak membicarakan, menulis tentang variabel yang ditelitinya. Kalau variabelnya adalah "Peran Kepala Desa", maka peneliti harus mempelajari konsep "peran Kepala Desa". Apa itu peran?. Peneliti tidak bisa hanya mengutip satu atau dua pendapat saja. Makin banyak pendapat para akhli yang dikutip, makin besar kemungkinan kebenaran makna definisi nominal variabel penelitiannya.

Untuk memudahkan, langkah awal yang bisa diambil guna menyusun definisi nominal variabel penelitian adalah melihat 
kamus umum. Kalau variabel tersebut berasal dari kata asing, misalnya dari bahasa Inggeris, maka kamus bahasa Inggeris yang dipakai. Baru setelah itu mencari dari buku-buku khusus yang membahas konsep atau variabel penelitiannya. Jika buku yang dibacanya cukup tebal sehingga sulit menemukan kata yang dicarinya, manfaatkan indeks yang ada di buku tersebut. Melalui indeks, peneliti dapat dengan mudah menemukan nomor halaman di mana kata yang dimaksudkan dibahas.

\section{Analisis Data}

Bagian ini diuraikan pendekatan statistik yang digunakan untuk menganalisis data yang akan dikumpulkan. Statistik yang statistik deskriptif dan (2) statistik inferensial terbagi atas parametrik dan non parametrik.

Pemilihan formula yan digunakan dalam menganalisis data sangat ditentukan oleh jenis data serta kesesuaian dengan tujuan dan hipotesis yang akan dibuktikan. Permasalahan yang diperhatikan dalam pemilihan teknik analisis adalah ketepatan formula yang digunakan untuk menganalisis bukan kecanggihan formula tersebut. 


\title{
IV. Penutup
}

\begin{abstract}
Penyusunan prosal penelitian diawali oleh kegiatan menemukan permasalahan sebagai titik awal kegiatan penelitian dilaksanakan. Setelah mempersiapkan berbagai kegiatan penunjang, peneliti menyusun proposal yang berisikan antara lain : (1) judul, (2) Latar belakang, (3) rumusan masalah, (4) tujuan penelitian, (5) kegunaan penelitian, (5) kerangka berfikir, (6) hipotesis, (7) metode peneltian, yang berisikan : (a) pemilihan metode, (b) populasi dan sampel, (c) teknik pengumpulan data, (d) perumusan definisi operasional, (e) analisis data.
\end{abstract}




\section{DAFTAR KEPUSTAKAAN}

Anderson, J.A. (1984) Public Policy - Making. Edisi ke Tiga. Holt, Rinehart and Winston, Inc

Alkin, M.C. (1985). A Guide for Evaluation Decision Makers. Baverly Hills : Sage

Borg, W.R. and Gall M.D. (1989). Educational Research. Edisi kelima. New York. New York : Longman.

Brewer, G.D \& de leon. P. (1983). The Foundation of policy Analysis. Pacific Groove, C.A : Brook / Cole Publishing Company Cooley, W.. \& Bickel, W. (1986). Decision Oriented Educational Research. Boston : Kluwer - Nijhoff Publishing

Direktorat Jenderal Pendidikan Tinggi, (1989). Petunjuk Pelaksanaan Pengelolaan Penelitian di Direktorat Jenderal Pendidikan Tinggi. Jakarta : Dirjen Dikti

Dye, T.R. (1984), Understanding Public Policy. Edisi ke Empat. Englewood Cliffs. N.J : Prentice - Hall. Inc. 


\section{MAKALAH}

\section{TEKNIK PEMBUATAN PROPOSAL PENELITIAN}

( Disampaikan dalam Pelatihan Metodologi Penelitian untuk Dosen Politeknik Universitas Andalas )

Oleh

DR.Firman.MS

( Kepala Bidang Kemasyarakatan

Balitbang Prop.Sumbar) 